\title{
Tuloerot ja taloudellisen tuloksen vaihtelu kirjanpitotiloilla poikkileikkaus- ja aikasarja-analyysin valossa vuosina $1976-83$
}

\author{
MARKKU NEVALA ja YRJÖ OJANIEMI \\ Maataloustuottajain Keskusliitto, 00100 Helsinki
}

\section{Income differences and variations in the economic results on Finnish book-keeping farms in 1976-83}

\author{
MARKKU NEVALA and YRJÖ OJANIEMI \\ The Central Union of Agricultural Producers, Helsinki, Finland
}

\begin{abstract}
Yearly variations in the economic results and income differences among the Finnish family farms were analyzed in this study. The main purpose was to find out the income and profitability distribution of the farms and trends of them during the last decade. In addition, the stability of the economic results of the farms in the different years of the research period was analyzed.

Analyses were based on statistics of the Finnish book-keeping farms in the years 1976-83. To eliminate the problems caused by the changes in the sample of book-keeping farms, the final analyses were based on a subsample of those farms, where the data was available for all the years. The total number of these farms was 617 . Farm family income and the coefficient of profitability were the economic concepts analyzed in the study. The latter one expresses the imputed wage of farm family and the interest claim for total capital as a share of net income.

Distribution of farm family income and profitability and the shape and location of the distribution in each year was analyzed by several statistical measures. The shape of income and profitability distributions was quite skewed which is typical for farm income distributions in all countries. Income differences and changes of income distribution during the research period were analyzed in more detail by using fractiles, quartiles and deciles. Also Lorenz-curves were calculated from the data.

The main conclusion drawn from the analyses was, that the relative income differences have not increased during the research period. On the other hand, it is worth while to point out that absolute income differences have nevertheless increased.

Analyses concerning the stability of the economic results of an individual farm over the research period indicate quite big variation between the years. Only a half of the farms of the lowest quartile remain in this category in all the years.
\end{abstract}

Index words: income differences, income variations, farm family income, coefficient of profitability 


\section{Johdanto}

Maatalouselinkeinolle on tyypillistä taloudellisen tuloksen suuri vaihtelu niin eri tilojen välillä kuin myös samalla tilalla eri vuosien välillä. Tilojen luontaiset tuotantoedellytykset kuten esim. koko, viljavuus, alueellinen sijainti ja säätekijät ovat merkittävimmät vaihtelua aiheuttavat tekijät. Lukuisissa tutkimuksissa on kuitenkin osoitettu, että itse viljelijäperheestä, sen taidosta ja kyvystä riippuvat tekijät vaikuttavat varsin paljon tilan taloudelliseen tulokseen. Maatalouspolitiikan ja varsinkin hinta- ja tulopolitiikan painotusten on myös sanottu vaikuttavan siihen, miten erot taloudellisessa tuloksessa maatiloilla kehittyvät ajan mittaan.

Maassamme aikaisemmin tehdyt väestöryhmittäistä tulonjakoa tai maatalouden sisäisiä tuloeroja käsittelevät tutkimukset ovat kuvanneet ensisijaisesti erilaisten tilaryhmien keskimääräisissä tuloissa esiintyvää vaihtelua. Tavoitteena tällöin on yleensä ollut selvittää mm. maatilojen alueellisesta sijainnista, tuotantosuunnasta ja tilakoosta johtuvia tuloeroja. Sen sijaan tilatason aineistoon perustuvat jakaumatarkastelut ja aikasarja-analyysit ovat olleet varsin harvinaisia. Tätä on pidettävä puutteena, sillä keskiarvotarkastelu vääristää esimerkiksi tulotasovertailuissa johtopäätöksiä jakaumien luonteen ja vinouden takia.

Eri tuloslukujen hajontaa sekä tulojakauman muotoa suomalaisilla maatiloilla on selvitetty mm. SuOMElan (1952), Torvelan (1966) ja Ihamuotılan (1979) tutkimuksissa. Pääosassa niitä tutkimuksia, jotka ovat käsitelleet yksittäisten tilojen tuloissa esiintyvää vaihtelua, on kuitenkin selvitetty ensisijaisesti vaihteluiden syitä. Näistä mainittakoon mm. RYYNÄSEN (1970) tutkimus tuotantofunktioista, sekä MiKKOLAN (1983) ja TURKIN (1982) tutkimukset. Koska nämä tutkimukset ovat painottuneet tulonvaihtelua aiheuttavien tekijöiden analysointiin, on tutkimusaineisto yleensä ollut varsin homogeeninen. Aineiston tilat ovat edustaneet yleensä yhtä tuotantosuuntaa, tilakokoluokkaa ja/tai aluetta.

Mielenkiintoisimpia tutkimuksia tulojakau- mien muodosta ja tuloerojen syistä eräistä Euroopan maista ovat viime vuosina tehneet mm. WitZKe (1983), Cordts et al. (1983) sekä ZACHARIASSE (1977). Varsin perusteellinen analyysi hintapolitiikan vaikutuksista maatalouden sisäiseen tulonjakoon sisältyy WITZ KEn (1979) Länsi-Saksasta sekä SNEESSENSin (1979) vastaavasti Belgiasta tekemiin tutkimuksiin. WiTZKEn tutkimustulosten mukaan maataloustuotteiden hintojen nostaminen kaventaa lyhyellä aikavälillä maatalouden sisäisiä tuloeroja, kun taas pitkällä aikavälillä tuloerot kasvavat.

Erilaisten tilaryhmien keskimääräisissä tuloissa esiintyvää vaihtelua ovat maassamme selvittäneet mm. AALtonEN (1981) ja HaNHILAHTI (1980). Näissä tutkimuksissa on tarkasteltu lähinnä eri alueiden välisiä toimeentuloeroja sekä aluetuen vaikutusta tuloeroihin.

EC:n jäsenmaiden viljelijöiden tulotasosta on tehty tutkimus, jossa verrattiin tuloeroja sekä jäsenmaiden sisällä että maiden välillä (Anon. 1985). Merkittäessä koko talousyhteisön työpanosyksikköä kohden lasketun maataloustulon keskiarvoa luvulla 100, saatiin koko yhteisön osalta parhaiten ansaitsevan neljänneksen tuloksi 236 ja heikoimman neljänneksen tuloksi 12. Vastaavat luvut jäsenmaiden sisällä vaihtelivat niin ikään merkittävästi. Hollannissa luvut olivat 453 ja 92 , ja Italiassa 163 ja 9.

Tulonjakoa ja väestöryhmien välisiä tuloeroja käsitteleviä tutkimuksia ovat maassamme tehneet mm. SuOMINen (1977 ja 1979), UUSITAlo (1982) sekä Hagfors ja KolJoNEN (1984). SUOMISEN (1977 ja 1979) tutkimuksissa tarkasteltiin kotitaloustiedustelujen pohjalta tulonsiirtojen, verotuksen ja yhteiskunnallisten hyödykkeiden vaikutusta tulojen uudelleenjakoon. Kyseisessä tutkimuksessa tarkasteltiin myös eri toimeentulotasoille sijoittuneiden kotitalouksien välisiä tuloeroja ja tuloerojen kehitystä sekä erityyppisten kotitalouksien sijoittumista eri toimeentulotasoille.

Tulopolitiikan vaikutuksia tulonjakoon pidemmällä ajanjaksolla on tutkinut $\mathrm{mm}$. UuSITALo (1982). Tutkimuksessa todetaan, että tuloerojen kehitys kääntyi kapenevaan suun- 
taan siirryttäessä ns. tulopolitiikan kauteen v. 1969, josta lähtien tuloerot ovat kaventuneet. Tosin v. 1975 paikkeilla tuloerojen tasoittumiskehitys on pysähtynyt (UUSITALo 1982, s. 73).

\section{Tutkimusongelma}

Maatalouden sisäisen tulonjaon ja taloudellisen tuloksen kehityksestä esitetään sellaisia mielipiteitä, että tuloerot maatilojen välillä olisivat kasvaneet esimerkiksi maatalouspoliittisen välineistön ja harjoitetun maatalouden hintapolitiikan seurauksena. Tällaisia väitteitä on yleensä pyritty perustelemaan koko sektoria koskevilla tai eri tilaryhmistä lasketuilla keskiarvoluvuilla.

Jakaumat ova kuitenkin yleensä erittäin vinoja ja niiden muoto on tämän lisäksi saattanut muuttua ajan kuluessa. Näin ollen pelkät keskiarvot eri tilaryhmistä eivät useinkaan kuvaa oikealla tavalla tulotasoeroja maataloussektorin sisällä eikä varsinkaan tulotason ja kannattavuuden kehitystä ajan mittaan (vrt. UusITALO 1982). Niin ikään tilojen lukumäärän vähenemisen ja tilastojen pohjana olevien tilojen vaihtuvuuden aiheuttamaa ongelmaa ei yleensä ole eliminoitu.

Tämän tutkimuksen tarkoituksena on kartoittaa maatilojen taloudellisen tuloksen ja tulotason vaihtelua tilatason aineistoon perustuen. Tavoitteena on tarkastella aikaisempaa perusteellisemmin nimenomaan eri tunnuslukujen vaihtelua ja jakaumia sekä yhden vuoden poikkileikkausaineiston että myös aikasarja-analyysin avulla. Painopiste on jakaumien muodon ja sisällön analysoinnissa. Vastausta haetaan erityisesti seuraaviin peruskysymyksiin:

1 Kuinka suuri taloudellisen tuloksen vaihtelu on ja mikä on jakauman muoto?

2 Ovatko taloudellisen tuloksen vaihtelu ja tuloerot Suomen maatiloilla kasvaneet ajan kuluessa?

3 Miten vakaa ja pysyvä on yksittäisen tilan taloudellinen tulos vuosien mittaan ja muut- tuuko se esimerkiksi suhteessa muiden tilojen kehitykseen?

Näitä ominaisuuksia ja ilmiöitä pyritään seuraavassa analysoimaan tilastollisilla jakauman sijaintia, hajontaa ja epäsymmetrisyyttä kuvaavilla tunnusluvuilla. Näitä tärkeämpi on kuitenkin fraktiilitarkastelu, jolla voidaan paremmin tutkia jakaumaa ja eri tyyppisten tilojen sijoittumista jakaumassa. Niin ikään kolmannessa kohdassa mainitut yksittäisen tilan aseman muutokset "tilajonossa» arvioidaan fraktiilitarkasteluna.

Taloudellista tulosta ja tuloeroja voidaan mitata varsin monella eri käsitteellä, jotka saattavat samaankin aineistoon sovitettuna antaa varsin erilaisen kuvan vallitsevasta tilanteesta. Puuttumatta kovin syvällisesti tähän mittaamisproblematiikkaan (vrt. WITZKE 1983, ym.), on tässä tutkimuksessa keskitytty lähinnä kahteen tunnuslukuun: maatalousylijäämään ja kannattavuuskertoimeen. Tämä valinta perustuu lähinnä aineiston asettamiin rajoituksiin. Kun tutkimuksessa tarkastellaan noin 1000 tilan kirjanpitoaineistoa kaikkiaan kahdeksalta vuodelta, muodostuu numeromateriaalista varsin mittava. Toisaalta voi väittää, että mainitut kaksi tunnuslukua antavat varsin monipuolisen ja kattavan kuvan maatilan taloudellisesta tuloksesta esimerkiksi aikasarja-analyysia varten.

\section{Tutkimusaineisto ja sen käsittely}

Tämän tutkimuksen analyysit perustuvat Maatalouden kannattavuustutkimuksen kirjanpitotilojen tuloksiin vuosilta 1976-83. Kirjanpitotilojen lukumäärä tutkimusajanjakson eri vuosina on vaihdellut $828-1107$ tilan välillä. Uusia tiloja on tullut mukaan kirjanpitotoimintaan ja osa tiloista on lopettanut kirjanpitotoiminnan tutkimusajanjaksolla.

Tilojen vaihtuvuudesta aiheutuvat vinoutumat tuloksissa haluttiin tässä analyysissä poistaa. Siksi lopulliseen aineistoon poimittiin kirjanpitotiloista vain ne tilat, jotka ovat mukana kaikkina vuosina 1976-83. Näitä löytyi yhteensä 617 tilaa. Koska tilajoukko on py- 
synyt samana, voidaan tuloksista ilmenevää tulotason ja kannattavuuden muutosta ja vaihtelua pitää todellisuutta vastaavana, eikä sitä sekoita heikoimpien ja pienimpien tilojen poisjäänti.

Koko maamme tilajoukko ei tutkimusajanjaksona ole pysynyt samana, vaan tilojen lukumäärä on vähentynyt varsin voimakkaasti. Lopettaneet tilat ovat useimmiten olleet pienimpiä sekä heikoimmin kannattavia. Tästä syystä on selvää, että koko maatalouden osalta tilastot osoittavat näennäisesti parempaa tulotason kehitystä kuin mitä todellisuudessa tuotantoa jatkavilla tiloilla on tapahtunut (vrt. esim. Uusitalo 1982, s. 77-79). Tämän tutkimuksen tuloksista nähtävissä oleva tulojen hajonta ja tulotaso kuvaa kehitystä tuotantoa jatkavilla tiloilla. Korostettakoon, että myös tämän tutkimuksen aineiston tiloilla on tapahtunut peltoalan lievää kasvua.

\section{Tutkimustulokset}

\subsection{Tunnuslukujen vaihtelu}

Taloudellisen tuloksen vaihtelua ja kehitystä tarkastellaan sekä kannattavuuskertoimen että maatalousylijäämän (mk/tila) avulla. Näiden molempien tunnuslukujen tarkastelu on katsottu tarpeelliseksi, koska tiloilla käytetty työpanos ja maatalouteen sijoitetun pääoman määrä vaihtelevat huomattavasti eri tiloilla ja kehittyvät eri tavalla ajan kuluessa. Suurten satunnais- ja vuosivaihteluiden vuoksi tässä tutkimuksessa laskettiin tunnusluvuista liukuvat kolmen vuoden keskiarvot. Todettakoon kuitenkin, että kaikkea sääolosuhteista johtuvaa satunnaisvaihtelua ei tälläkään tavalla ole voitu eliminoida. Sääoloiltaan poikkeukselliset vuodet jakautuivat nimittäin peräkkäin tarkasteluajanjaksolla (vuodet 1977, 1978, 1979).

\section{Jakauman vinous}

Maatalousylijäämän jakauma oli vasemmalle kallistunut jokaisena tutkimusajanjakson vuotena. Tässä tapauksessa mediaanitu- lo on siis selvästi keskimääräistä tuloa pienempi. Kun palkansaajien osalta tulojakaumat eivät yleensä ole näin vinoja, keskiarvot antavat näin ollen liian hyvän kuvan viljelijöiden tulotasosta esimerkiksi väestöryhmien välisissä vertailuissa. Jakauman muotoa kuvaava vinouskerroin (S) vaihteli maatalousylijäämästä tilaa kohden laskettuna välillä $0,93-2,59$.

Kun jakauman vinouskerroin on näin suuri, keskihajonnan ja variaatiokertoimen informaatioarvo on varsin heikko kuvattaessa jakauman hajonnan suuruutta (CORDTS et al. 1984, s. 327). Tarkemman kuvan saamiseksi jakauman ominaisuuksista tarvitaankin fraktiilitarkastelua. Toisaalta jakauma on kaikkina tutkimusvuosina samaan suuntaan vino, joten keskihajonnan ja variaatiokertoimen muutokset kuvastavat kohtalaisen hyvin jakaumassa tapahtunutta kehitystä. Maatalousylijäämän jakauma vuosina 1977 ja 1978, jolloin vinouskertoimet saivat ääriarvonsa, esitetään kuviossa 1 .

Kannattavuuskertoimen ja maatalousylijäämän hajonta

Tutkimustilojen keskimääräinen maatalousylijäämä ja kannattavuuskerroin vaihte-

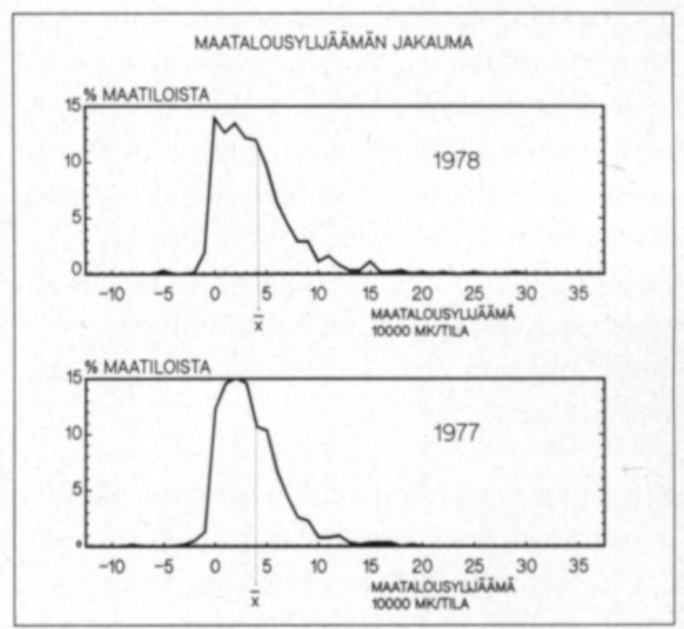

Kuvio 1. Maatalousylijäămän jakauma ja keskiarvo tutkimustiloilla vuosina 1977 ja 1978.

Fig. 1. The distribution of farm family income in 1977 and 1978. 
Taulukko 1. Maatalousylijäămän jakauman vinouskerroin vuosina 1976-83.

Table 1. The coefficient of skewness (S) of the distribution of farm family income in 1976 -83 .

\begin{tabular}{lccc}
\hline Vuosi & $\begin{array}{c}\text { Vinous- } \\
\text { kerroin }\end{array}$ & Vuosi & $\begin{array}{c}\text { Vinous- } \\
\text { kerroin }\end{array}$ \\
Year & $\begin{array}{c}\text { Coefficient } \\
\text { of skewness } \\
\text { S }\end{array}$ & Year & $\begin{array}{c}\text { Coefficient } \\
\text { of skewness } \\
\text { S }\end{array}$ \\
\hline 1976 & 2,19 & 1980 & 2,27 \\
1977 & 0,93 & 1981 & 1,07 \\
1978 & 2,59 & 1982 & 1,36 \\
1979 & 2,11 & 1983 & 1,80 \\
\hline
\end{tabular}

livat varsin paljon vuodesta toiseen. Yksittäisten tilojen eri vuosien tuloksissa esiintyvää vaihtelua ei erikseen selvitetty. Taulukossa 2 esitetään tutkimustilojen keskimääräinen kannattavuuskerroin ja maatalousylijäämä sekä maatalousylijäämän keskihajonta sekä minimi- ja maksimiarvot aineistossa.

Tutkimusaineiston viimeisenä vuotena 1983 maatalousylijäämän keskihajonta oli tutkimustiloilla $91620 \mathrm{mk}$, kun keskiarvo oli 110568 mk. Keskihajonnan ja keskiarvon suhdetta ja suhteellista muutosta on tässä tutkimuksessa tarkasteltu variaatiokertoimen avulla. Tällä voidaan mitata jakaumien hajontaa mittayksiköstä riippumatta, joten se so- veltuu hyvin eri vuosien väliseen vertailuun sekä kehityksen seurantaan (CORDTs et al. 1984, s. 329). Tulokset tämän tutkimuksen aineistosta laskettuna esitetään taulukossa 3 .

Koko tutkimusajanjakson keskimääräinen, hajontaa kuvaava variaatiokerroin oli maatalousylijäämästä laskettuna 87,13 ja kannattavuuskertoimesta laskettuna 77,78. Kansainvälisesti tarkasteltuna luvut eivät ole poikkeavia. CordTs et al. (1984, s. 331) saivat tutkimuksessaan Länsi-Saksan maatiloilta samansuuruisia lukuja: työntekijää kohti lasketun maataloustulon variaatiokerroin oli tutkitussa tilajoukossa keskimäärin 78,0 (vuosina 196880).

Kannattavuuskertoimen variaatiokerroin oli suurimmillaan vuonna 1978: 90,76. Maatalousylijäämän variaatiokerroin sai myös suurimman arvonsa samana vuonna ja oli silloin 96,76. Kaikkina vuosina taloudellisen tuloksen hajonta aineiston tiloilla oli maatalousylijäämällä mitattuna hieman suurempi kuin kannattavuuskertoimella mitattuna. Kannattavuuskerroin näyttää näin ollen eliminoivan jonkin verran pääoman sekä työpanoksen määrästä johtuvia vaihteluita.

Variaatiokertoimien mukaan maatalousylijäämän hajonta lisääntyi jonkin verran tutkimusajanjakson alkupuoliskolla ja väheni ajanjakson loppupuoliskolla. Kokonaisuute-

Taulukko 2. Taloudellista tulosta kuvaavia tunnuslukuja tutkimustiloilla vuosina $1976-83$.

Table. 2. Economic results of the investigated farms in 1976-83.

\begin{tabular}{|c|c|c|c|c|c|c|}
\hline \multirow{4}{*}{$\begin{array}{l}\text { Vuosi } \\
\text { Year }\end{array}$} & \multirow{4}{*}{$\begin{array}{l}\text { Kann.kerroin } \\
\text { keskiarvo }\end{array}$} & \multicolumn{2}{|c|}{ Maatalousylijäämả } & \multicolumn{2}{|c|}{ Maatalousylijäămä } & \multirow{2}{*}{$\begin{array}{c}\text { Vaihtelu- } \\
\text { văli }\end{array}$} \\
\hline & & $\begin{array}{l}\text { keski- } \\
\text { arvo }\end{array}$ & $\begin{array}{c}\text { keski- } \\
\text { hajonta }\end{array}$ & $\begin{array}{l}\text { minimi- } \\
\text { arvo }\end{array}$ & $\begin{array}{c}\text { maksimi- } \\
\text { arvo }\end{array}$ & \\
\hline & & \multicolumn{2}{|c|}{ Farm family income } & \multicolumn{2}{|c|}{ Farm family income } & \multirow[t]{2}{*}{ Range } \\
\hline & & Average & Std & $\begin{array}{c}\text { Minimum } \\
\text { value }\end{array}$ & $\begin{array}{l}\text { Maximum } \\
\text { value }\end{array}$ & \\
\hline 1976 & 0,81 & 44180 & 37992 & -29854 & 295118 & 324972 \\
\hline 1977 & 0,61 & 38416 & 32678 & -120350 & 195364 & 315714 \\
\hline 1978 & 0,62 & 42976 & 41584 & -58399 & 421711 & 480110 \\
\hline 1979 & 0,70 & 52602 & 48505 & -103011 & 413968 & 516969 \\
\hline 1980 & 0,85 & 68462 & 58863 & -28966 & 574475 & 603441 \\
\hline 1981 & 0,70 & 64346 & 54582 & -202208 & 339426 & 541634 \\
\hline 1982 & 0,99 & 92671 & 77207 & -268412 & 491946 & 760358 \\
\hline 1983 & 1,08 & 110568 & 91620 & -83369 & 565977 & 649346 \\
\hline
\end{tabular}


na maatalousylijäämän hajonta näyttää pienenevän tutkimusajanjaksolla: variaatiokertoimien kolmen vuoden liukuvien keskiarvojen perusteella luvusta 89,27 lukuun 83,67 sekä kannattavuuskertoimesta laskettuna luvusta 79,64 lukuun 74,15 .

Variaatiokertoimien muutoksista osa selittyy kasvukauden sääolosuhteista johtuvalla satunnaisvaihtelulla. Tämä vaikutus näkyy sekä eri vuosien maatalousylijäämän keskimääräisen tason vaihtelussa että myös yksittäisen vuoden hajonnan suuruudessa. Luvuista ei voi kuitenkaan päätellä, onko yksittäisen vuoden sisäisellä hajonnalla ja eri vuosien keskimääräisen tulotason vaihtelulla selvää riippuvuutta keskenään. CordTs et al. (1983, s. 4-5) totesivat tutkimuksessaan, että tulojen hajonta samana vuonna johtuu eri tekijöistä kuin vuosien välinen vaihtelu. Katovuonna 1978 maatalousylijäämän variaatiokerroin oli ajanjakson suurin ja vastaavasti maatalousylijäämän keskiarvo reaalisesti ajanjakson pienin.

\subsection{Vaihtelun suuruus ja kehityssuunta: Fraktiilitarkastelu}

Maatalouden taloudellisen tuloksen jakauman ominaisuuksien ja niissä tapahtuneiden muutosten arvioimiseksi aineiston tilat ryhmiteltiin tuloluokkiin. Tämä luokittelu perustuu aineiston normaaliin kvarttiili- ja desiilijakoon. Tilat on asetettu jokaisena tutkimusvuotena tulojen mukaan suuruusjärjestykseen ja syntynyt "tilajono" on jaettu yhtä suuriin ryhmiin. Tällöin kvarttiilijaon mukaisissa luokissa on kussakin $25 \%$ tiloista ja desiilijaon mukaisissa luokissa $10 \%$ tiloista (vrt. HAGFORS ja KolJonen 1984 , s. $8-18$, Anon. 1985 , s. 3-4).

Maatalousylijäämään perustuva neljännesluokittelu ja eri luokkien keskiarvot sekä niiden kehitys on esitetty taulukossa 4 .

Alimman neljänneksen keskimääräinen maatalousylijäämä on varsin alhainen kaikkina tutkimusvuosina, joskin siinä on havait-

Taulukko 3. Maatalousylijăămän (mk/tila) ja kannattavuuskertoimen variaatiokertoimet (V) tutkimustiloilla vv. 1976-83.

Table 3. The percent coefficient of variation of farm family income and profitability coefficient in $1976-83$.

\begin{tabular}{|c|c|c|c|c|c|c|}
\hline \multirow{3}{*}{$\begin{array}{l}\text { Vuosi } \\
\text { Year }\end{array}$} & \multicolumn{3}{|c|}{ Maatalousylijäămä } & \multicolumn{3}{|c|}{ Kannattavuuskerroin } \\
\hline & V1 & $\mathrm{V} 2$ & V3 & V1 & V2 & V3 \\
\hline & \multicolumn{3}{|c|}{ Farm family income } & \multicolumn{3}{|c|}{ Profitability coefficient } \\
\hline \multirow[t]{2}{*}{1976} & 85,99 & & & 70,07 & & \\
\hline & & 85,53 & & & 74,08 & \\
\hline \multirow[t]{2}{*}{1977} & 85,06 & & 89,27 & 78,08 & & 79,64 \\
\hline & & 91,38 & & & 84,42 & \\
\hline \multirow[t]{2}{*}{1978} & 96,76 & & 91,34 & 90,76 & & 84,53 \\
\hline & & 94,49 & & & 87,56 & \\
\hline \multirow[t]{2}{*}{1979} & 92,21 & & 91,65 & 84,35 & & 83,88 \\
\hline & & 89,10 & & & 80,45 & \\
\hline \multirow[t]{2}{*}{1980} & 85,98 & & 87,67 & 76,54 & & 80,10 \\
\hline & & 85,41 & & & 77,98 & \\
\hline \multirow[t]{2}{*}{1981} & 84,83 & & 84,71 & 79,41 & & 76,50 \\
\hline & & 84,07 & & & 76,48 & \\
\hline \multirow[t]{2}{*}{1982} & 83,31 & & 83,67 & 73,55 & & 74,15 \\
\hline & & 83,09 & & & 71,52 & \\
\hline 1983 & 82,86 & & & 69,48 & & \\
\hline keskim. & 87,13 & & & 77,78 & & \\
\hline
\end{tabular}

$\mathrm{V} 1$ = variaatiokerroin kyseisenä vuotena

$\mathrm{V} 2$ = variaatiokertoimen kahden vuoden liukuva keskiarvo

$\mathrm{V} 3$ = variaatiokertoimen kolmen vuoden liukuva keskiarvo

$\mathrm{V} 1$ = percent coefficient of variation $(\mathrm{CV})$

$\mathrm{V} 2$ = two years moving average of $\mathrm{CV}$

$\mathrm{V} 3$ = three years moving average of $\mathrm{CV}$ 
tavissa suhteellisen suuria vaihteluita. Vuonna 1978 jäi alimman neljänneksen maatalousylijäämäksi keskimäärin vain 3634 markkaa, kun keskimääräinen arvo kaikilla tiloilla oli 42976 markkaa.

Reaalisen maatalousylijäämän (tukkuhintaindeksi deflaattorina) kasvu on ollut ylimmässä tuloneljänneksessä markkamääräisesti suurempi kuin alimmassa. Merkille pantavaa on, että aineistossa on kaikkina vuosina ollut myös sellaisia tiloja, joiden maatalousylijäämä on negatiivinen. Näitä tiloja on aineistossa varsin monia, sillä tilajoukon alimman kymmenyksen keskimääräinen maatalousylijäämä oli negatiivinen peräti viitenä vuotena (1977, 1978, 1979, 1981 ja 1982).

Kannattavuuskertoimen mukaan tehty neljännesluokittelu (K1 . . K4) ja keskimääräistä kehitystä osoittavat luvut eri kannattavuusneljänneksissä esitetään kuviossa 2 .

Heikoimman neljänneksen keskimääräinen kannattavuuskerroin oli alimmillaan vuonna 1978 eli 0,05 . Korkein arvo 0,35 saavutettiin alimmassa kannattavuusneljänneksessä vuonna 1983. Myös maatalousylijäämän mukaisessa luokittelussa ääriarvot alimmassa neljänneksessä esiintyivät samoina vuosina.

Vaihtelu eri vuosien välillä on suhteellisesti ottaen pienin toisessa ja kolmannessa neljänneksessä. Suurinta se on alimmassa neljän-
KESKIMĀĀRĀINEN KANNATTAVUUS ERI KANNATTAVUUSNELJĀNNEKSISSÄ

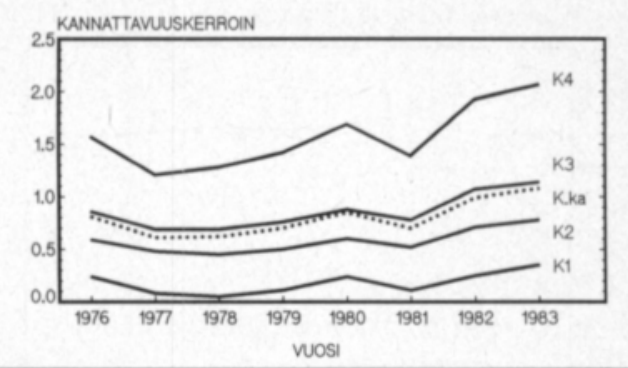

Kuvio 2. Kannattavuuskertoimen keskiarvo eri kannattavuusneljänneksissä vuosina 1976-83.

Fig. 2. The coefficient of profitability in different profitability quartiles in 1976-83.

neksessä. Kehitystä seurattaessa onkin perusteltua laskea kolmen vuoden liukuvat keskiarvot eri neljänneksien tuloksista satunnaisvaihtelun vaikutuksen vähentämiseksi (vrt. WITZKE 1983, s. 36).

Kaikkina vuosina kolmannen neljänneksen keskimääräinen kannattavuuskerroin ja maatalousylijäämä ovat molemmat varsin lähellä koko aineiston keskimääräisiä arvoja. Tämä osoittaa havainnollisesti, että koko tilajoukon keskiarvot antavat näin vinoissa jakaumissa liian hyvän kuvan todellisesta taloudellisesta tuloksesta tilajoukossa.

Taulukko 4. Maatalousylijäămän keskiarvo eri tuloneljănneksissä vuosina $1976-83, \mathrm{mk} /$ tila.

Table 4. Farm family income in different income quartiles in 1976-83.

\begin{tabular}{|c|c|c|c|c|c|}
\hline \multirow{3}{*}{$\begin{array}{l}\text { Vuosi } \\
\text { Year }\end{array}$} & \multicolumn{4}{|c|}{ Neljännesten keskiarvot } & \multirow{2}{*}{$\begin{array}{c}\text { Koko aineisto } \\
\text { keskiarvo }\end{array}$} \\
\hline & Q1 & Q2 & Q3 & Q4 & \\
\hline & & \multicolumn{3}{|c|}{ The average of each quartile } & $\begin{array}{c}\text { Average of all } \\
\text { farms }\end{array}$ \\
\hline 1976 & 10249 & 27495 & 45431 & 93767 & 44180 \\
\hline 1977 & 4284 & 25268 & 43192 & 81143 & 38416 \\
\hline 1978 & 3634 & 26772 & 46470 & 95014 & 42976 \\
\hline 1979 & 6050 & 33213 & 57693 & 113752 & 52602 \\
\hline 1980 & 13809 & 42858 & 71443 & 146092 & 68462 \\
\hline 1981 & 8493 & 41843 & 69202 & 138208 & 64346 \\
\hline 1982 & 16729 & 58935 & 98977 & 196538 & 92671 \\
\hline 1983 & 25586 & 70733 & 113794 & 232710 & 110568 \\
\hline
\end{tabular}

Q1 = alin neljännes

Q2 = toiseksi alin jne.

Q1 = The first quartile

Q2 = The second quartile etc. 


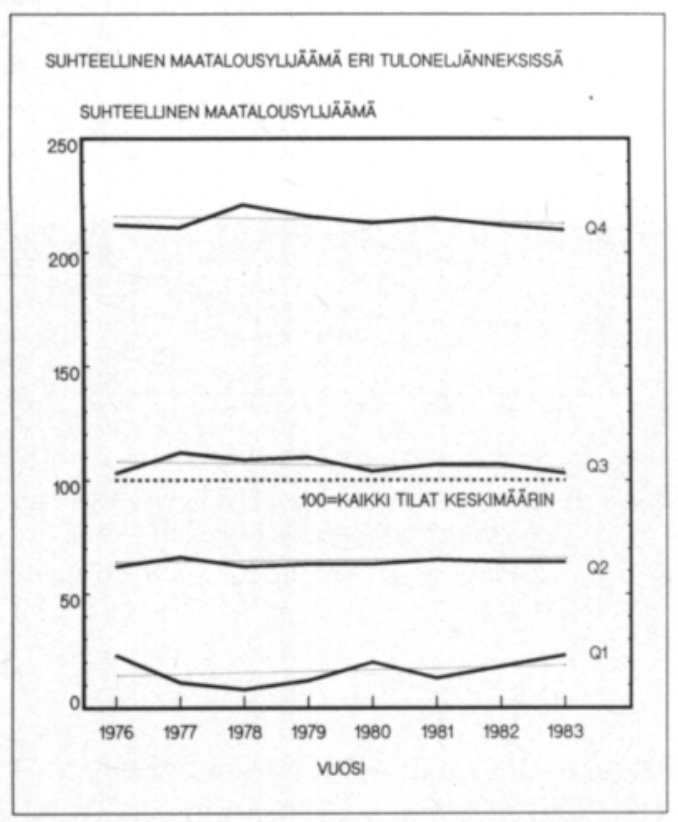

Kuvio 3. Eri neljänneksien maatalousylijäämă suhteessa kaikkien tilojen keskimääräiseen maatalousylijäämään, vuosina 1976-83, sekä ajanjakson trendiarvot.

Fig. 3. Level of farm family income in different income quartiles in 1976-83. $100=$ the average of all farms.

Kuviossa 3 on esitetty maatalousylijäämän suhteellinen kehitys eri neljänneksissä siten, että kaikkien tilojen keskimääräistä maatalousylijäämää on merkitty luvulla 100 jokaisena tutkimusvuotena.

Sekä maatalousylijäämän että kannattavuuskertoimen perusteella tehdyn tarkastelun mukaan tuloerot parhaimman ja heikoimman neljänneksen välillä eivät ole muuttuneet kovin oleellisesti tutkimusajanjakson kuluessa. Kuitenkin koko ajanjakson trendi osoittaa lievää tuloerojen kapenemista, kannattavuuskertoimella mitattuna hieman selvemmin kuin maatalousylijäämällä mitattuna. Näin ollen tämän tutkimuksen tulokset eivät tue väitettä siitä, että maatalouden sisällä suhteelliset tuloerot olisivat viime vuosina kasvaneet.

Parhaimman ja heikoimman neljänneksen keskimääräisen maatalousylijäämän suhde trendistä laskettujen lukujen perusteella on pienentynyt luvusta 15,8 (v. 1976) lukuun 11,5 (v. 1983). Maatalousylijäämän suhteellinen ta- so on alimmassa neljänneksessä kasvanut trendiarvon mukaan noin 0,7 prosenttiyksikköä vuodessa, kun vastaavasti ylimmässä neljänneksessä on tapahtunut noin 0,4 prosenttiyksikön lasku vuotta kohti.

Suhteelliset erot neljänneksien välillä olivat pienimmillään sekä maatalousylijäämällä että kannattavuuskertoimella mitattuna vuonna 1983. Jos kaikkien tilojen keskimääräistä maatalousylijäämää v. 1983 (110 568 mk) kuvataan luvulla 100 , niin vastaava taso parhaassa tuloneljänneksessä oli tällöin 210 ja heikoimmassa neljänneksessä 23. Kannattavuuskertoimista saadut luvut olivat vastaavasti 191 ja 32 .

Tuloerojen suuruutta on varsin vaikea verrata vastaavaan tilanteeseen muissa Euroopan maissa, sillä eri tutkimuksissa käytetyt tulokäsitteet, tilastoaineisto ja tarkastelutapa poikkeavat toisistaan. EC:n komission tekemässä tutkimuksessa (Anon. 1985) saatiin koko yhteisön osalta parhaan neljänneksen keskiarvoksi suhdeluku 236 ja heikoimmalle neljännekselle vastaavasti suhdeluku 12, kun yhteisön kaikkien tilojen keskimääräistä tasoa merkittiin luvulla 100. Eri jäsenmaiden osalta vastaavat suhdeluvut ovat seuraavat: Ita-

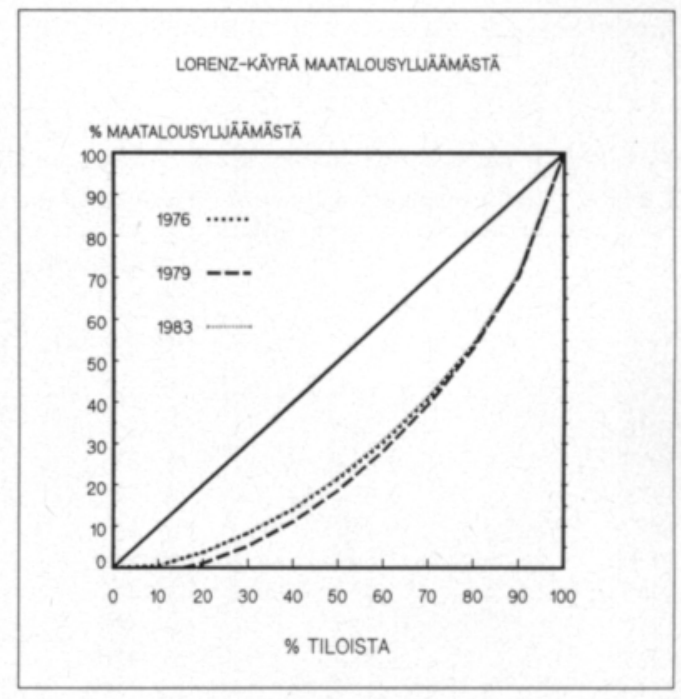

Kuvio 4. Lorenz-käyrät maatalousylijäämästä laskettuna vuosina 1976, 1979 ja 1983.

Fig. 4. Lorenz-curves of farm family income in 1976 , 1979 and 1983. 
lia 163 ja 9, Alankomaat 453 ja 92, Belgia 362 ja 79, Ranska 249 ja 30 ja Tanska 380 ja 76 .

Muutokset jakautumissa tutkimusajanjaksolla johtuvat paljolti sääolosuhteista. Vuodet 1977—79 sekä 1981 olivat Etelä-Suomessa varsin huonoja. Erityisesti alimman neljän- neksen tulotaso laski katovuosina sekä absoluuttisesti että suhteellisesti mitaten. Tämä näkyy myös tulojen hajontaa kuvaavan variaatiokertoimen kasvusta katovuosina. Tosin variaatiokerroin ei tässä suhteessa seurannut loogisesti keskimääräisen tulotason muutoksia.

\section{ERI ALUEIDEN TILAT}
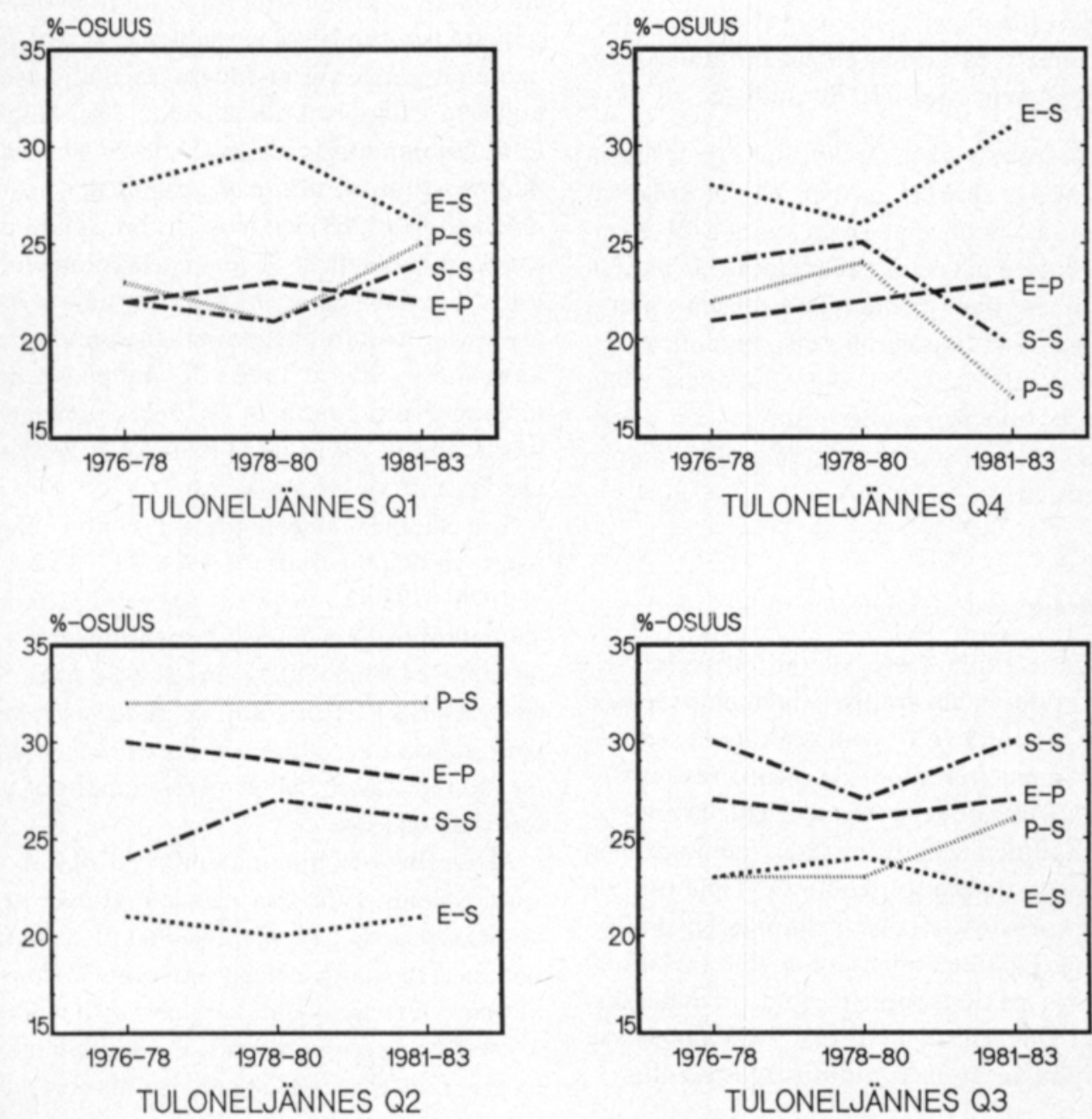

Kuvio 5. Eri alueiden tilojen jakautuminen eri tuloneljänneksiin aineiston alkupuoliskolla (1976-78), keskivaiheilla $(1978-80)$ ja loppupuoliskolla (1981-83).

Fig. 5. Distribution of the farms of located in different regions into different income quartiles. E-S = South Finland, S-S = Central Finland, E-P = South Ostrobothnia, P-S = North Finland. 
Maatalousylijäämä eri neljänneksissä

Alimpaan neljännekseen sijoittuneiden tilojen osuus koko tilajoukon yhteenlasketusta maatalousylijäämästä on vuonna 1976 vain vajaat $6 \%$. Vuonna 1979 vastaava luku oli $3 \%$ ja vuonna 1983 jälleen $6 \%$. Kahden alimman neljänneksen osalta vastaavat luvut olivat $21 \%, 19 \%$ ja $22 \%$.

Kuviossa 4 esitetään maatalousylijäämän suhteellinen jakautuminen kyseisinä vuosina Lorenz-käyrän avulla. Kuviossa osuudet on laskettu kumulatiivisesti alimmasta tulokymmenyksestä alkaen. Kuvion 4 lävistäjä osoittaa teoreettista tasajakaumaa, jolloin jokainen kymmenys saisi $10 \%$ tuloista.

Tuloeroissa ei ole tapahtunut kovin suuria muutoksia, sillä eri vuosien käyrät kulkevat lähes samalla tavalla. Tosin vuonna 1979 voidaan katsoa alhaisimmalla tulotasolla olevien tilojen aseman hieman heikenneen, mutta vuonna 1983 tilanne oli taas suunnilleen sama kuin vuonna 1976. Myös tämä tarkastelu osoittaa tuloerojen olleen ajanjakson puolivälissä hieman suuremmat kuin alku- ja loppuvuosina.

\section{Muutokset eri neljännesten sisällössä}

Tässä tutkimuksessa oli tarkoituksena selvittää tulojen määrällisen jakauman lisäksi myös sitä, onko erityyppisten tilojen suhteellinen asema »tulojonossa» olennaisesti muuttunut. Tämä on tehty tarkastelemalla erityyppisten tilojen sijoittumista eri neljänneksiin tarkasteluajanjakson kuluessa. Tältä osin on syytä korostaa, että eri neljännesten sisällön ja siinä tapahtuneiden muutosten tarkastelu ei kuvaa eri tilatyyppien tulotason määrällistä eikä suhteellista muutosta, vaan ainoastaan ko. ryhmän aseman muutosta asteikolla.

Koska satunnaisvaihtelut aiheuttavat tilapäisiä muutoksia eri tyyppisten tilojen sijoittumiseen tuloasteikolla on tarkastelussa käytetty kolmen vuoden keskiarvoja siten, että ajanjakson alkupuoliskoa kuvaavat vuosien 1976-1978 keskiarvot, puoltaväliä vuosien
1978 - 80 keskiarvot ja loppupuolta vuosien 1981-1983 keskiarvot.

\section{Eri alueiden tilat}

Tutkimusaineistossa Etelä-Suomen tilat ovat keskittyneet tulojonon ääripäihin: kahdessa keskimmäisessä tuloneljänneksessä EteläSuomen tiloja on suhteellisesti ottaen vähemmän kuin muissa neljänneksissä. Aikaisempien tutkimuksien perusteella voidaan päätellä, että alimpaan tuloneljännekseen sijoittuvat tilat ovat pieniä viljatiloja. Etelä-Suomen tilojen jakautumisessa eri neljänneksiin on tapahtunut jonkin verran muutoksia ajanjakson kuluessa. Alimpaan tuloneljännekseen kuului tutkimusajanjakson alkupuolella $28 \%$ EteläSuomen tiloista, mutta keskivaiheilla osuus nousi $30 \%$ :iin laskien taas tutkimusajanjakson loppupuolella $26 \%$ :iin. Etelä-Suomen tilojen aseman paraneminen on nähtävissä myös ylimmän tuloneljänneksen sisältöä tarkasteltaessa, sillä v. 1976—78 ylimpään tuloneljännekseen kuului $28 \%$ Etelä-Suomen tiloista, kun v. 1981-1983 luku oli $31 \%$ (Kuvio 5).

Sisä-Suomen alueen tiloista kuului alimpaan tuloneljännekseen v. 1976-1978 $22 \%$, v. $1978-198021 \%$ ja v. $1981-198326 \%$. Ylimmässä neljänneksessä prosenttilukema on laskenut $24 \%$ :sta $20 \%$ :iin. Sisä-Suomen tilat ovat siis siirtyneet tulojonossa selvästi alaspäin, mutta ovat silti keskittyneet vielä ajanjakson lopussakin kahteen keskimmäiseen tuloneljännekseen.

Myös Etelä-Pohjanmaan alueen tilat ovat valtaosaltaan kahdessa keskimmäisessä neljänneksessä. Ne ovat ajanjakson kuluessa parantaneet hieman asemaansa tuloasteikolla, eli tiloja on siirtynyt kahdesta alimmasta neljänneksestä kahteen ylimpään. Pohjois-Suomen alueen tilat ovat sen sijaan kehittyneet heikompaan päin. Suurin siirtyminen on tapahtunut ylimmästä tuloneljänneksestä, jossa tulotaso on selvästi keskimääräistä korkeampi. Ajanjakson alkupuoliskolla kuului ylimpään tuloneljännekseen vielä $22 \%$ Pohjois-Suomen tiloista, mutta loppupuoliskolla ainoas- 


\section{ERI TUOTANTOSUUNNAT}

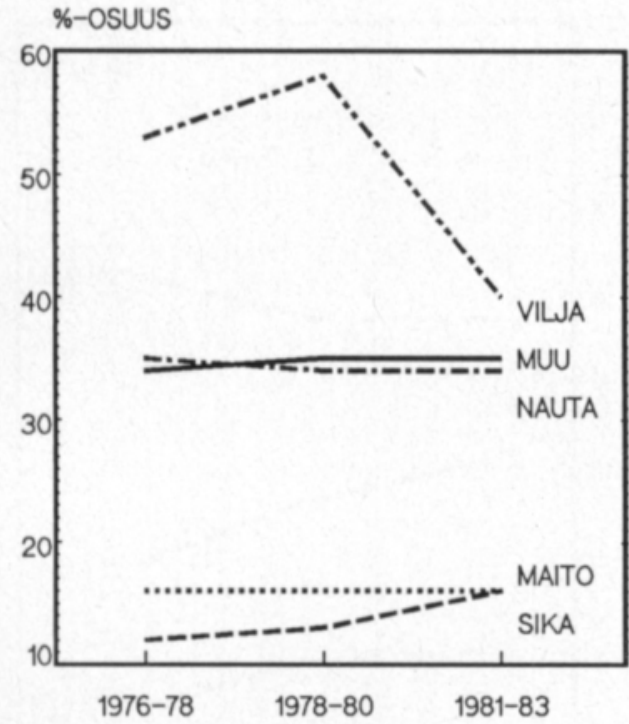

TULONELJÄNNES Q1

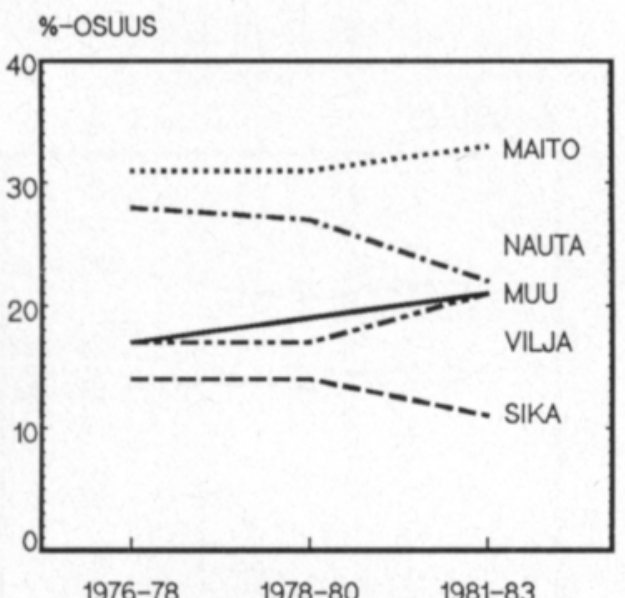

TULONELJÄNNES Q2

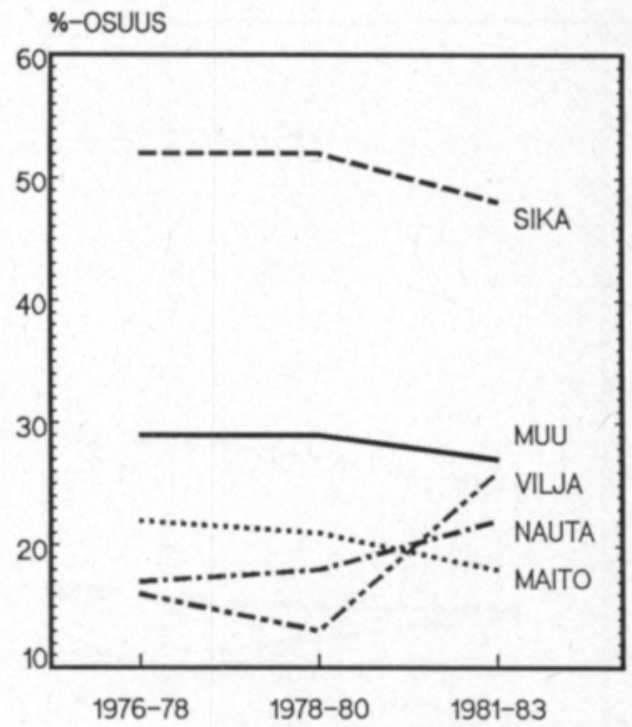

TULONELJÄNNES Q4

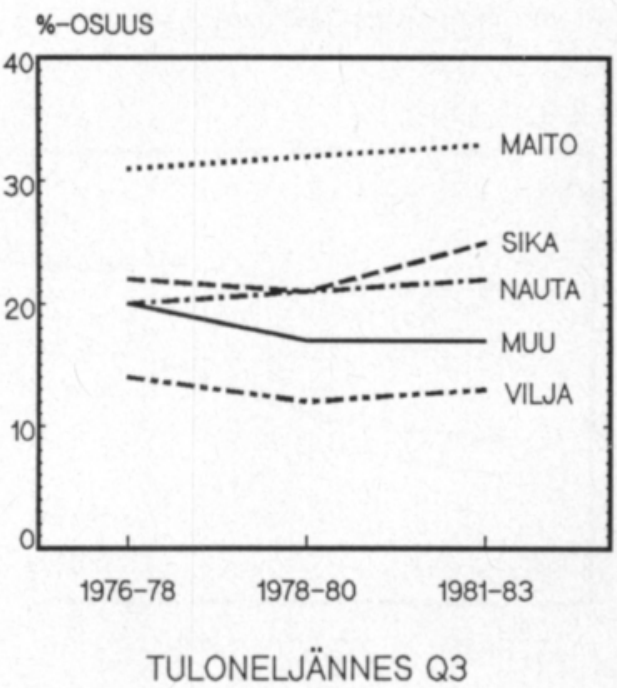

Kuvio 6. Eri tuotantosuuntaa harjoittavien tilojen jakautuminen eri tuloneljänneksiin keskimäärin vuosina 1976-78, $1978-80$ ja $1981-83$.

Fig. 6. Distribution of farms producing different products into different income quartiles. Maito = milk farms, Nauta $=$ mixed milk \& beef farms, Sika $=$ pork farms, Vilja $=$ cereal farms, Muu $=$ other farms. 


\section{ERI TILAKOKOLUOKAT}

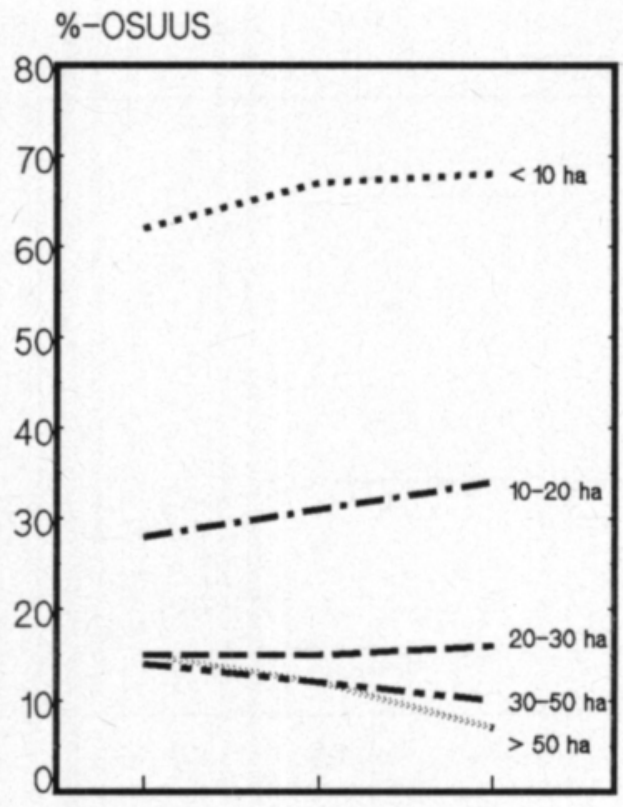

1976-78 1978-80 1981-83

TULONELJÄNNES Q1

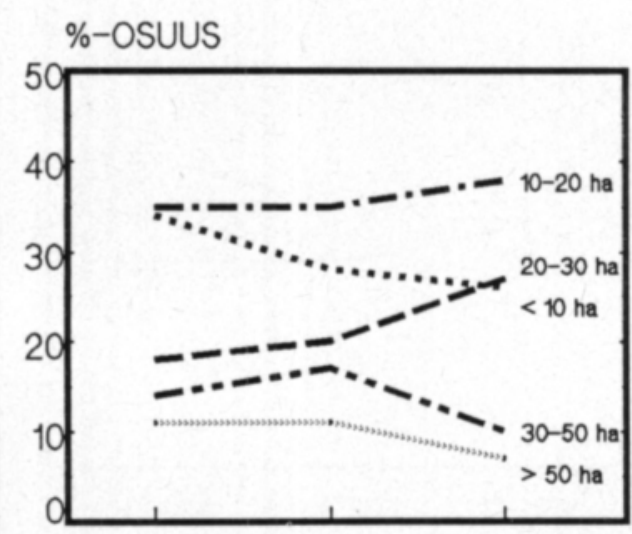

1976-78 1978-80 1981-83

TULONELJÄNNES Q2

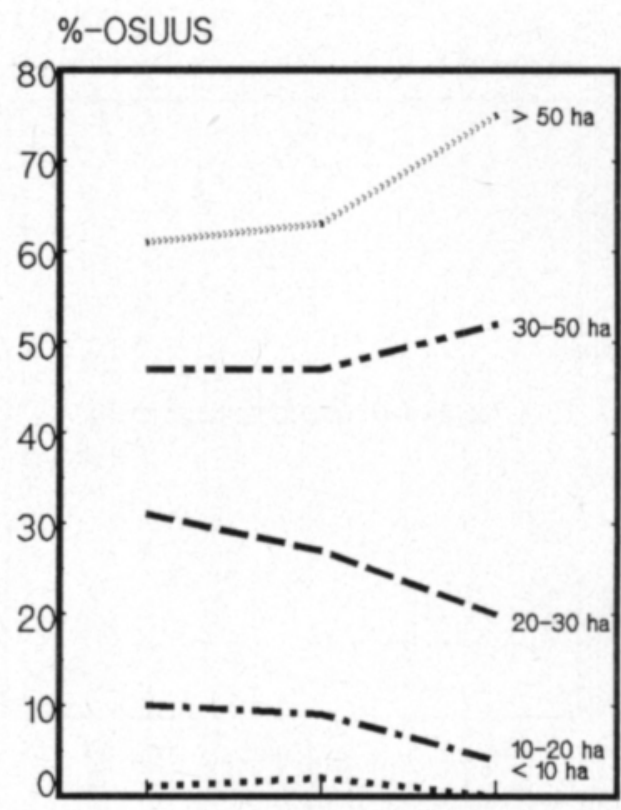

1976-78 1978-80 1981-83

TULONELJÄNNES Q4

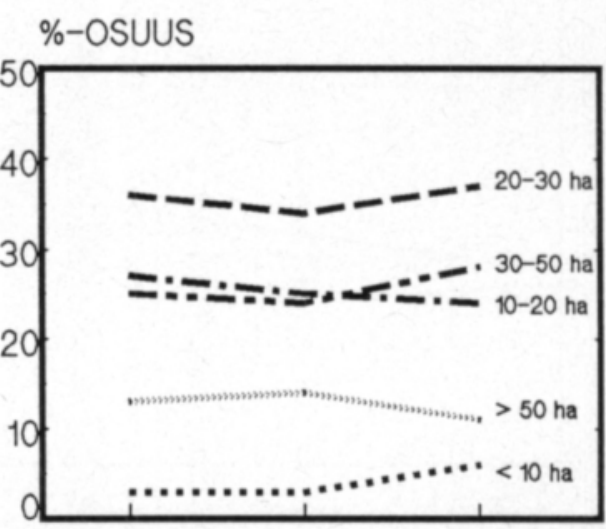

1976-78 1978-80 1981-83

TULONELJÄNNES Q3

Kuvio 7. Eri tilakokoluokkiin kuuluvien tilojen jakautuminen eri tuloneljänneksiin keskimăärin vuosina 1976-78, 1978-80 ja 1981-83.

Fig. 7. Distribution of farms of different size (according to the arable land) in different income quartiles 
taan $17 \%$. Vastaavasti alimmassa neljänneksessä oli alkupuoliskolla $23 \%$ Pohjois-Suomen tiloista ja loppupuoliskolla $25 \%$.

\section{Eri tuotantosuunnat}

Eri tuotantosuuntaa harjoittavien tilojen sijoittuminen tuloasteikolla on muuttunut tutkimusajanjakson kuluessa melko selvästi. Tämä on suurelta osin seurausta siitä, että tuotteiden hintasuhteet muuttuivat ajanjakson loppupuoliskolla viljan eduksi. Tarkasteltaessa eri tuotantosuuntia edustavien tilojen sijoittumista on kuitenkin muistettava, että kysymys ei ole saman tilakokoluokan tiloista, vaan tuotantosuuntien välillä keskimääräinen peltoala vaihtelee. Esimerkiksi sikatilojen keskimääräinen pinta-ala on jonkin verran muita suurempi.

Maitotilat ovat keskittyneet selvästi kahteen keskimmäiseen tuloneljännekseen. Keskittyminen on voimistunut tutkimusajanjakson kuluessa, sillä v. 1976-1978 kaikista maitotiloista oli sekä toisessa että kolmannessa neljänneksessä $31 \%$, ja v. 1981-1983 vastaavasti $33 \%$. Ylimpään neljännekseen kuuluvien maitotilojen osuus on vastaavasti vähentynyt $22 \%$ :sta $18 \%$ :iin (Kuvio 6).

Nautakarjatilat ovat yleensä keskittyneet joukon alapäähän, sillä alimpaan neljännekseen kuului kaikkina vuosina noin $35 \%$ nautakarjatiloista. Niiden osuus toisessa neljänneksessä on selvästi laskenut ja kahdessa ylimmässä neljänneksessä vastaavasti kasvanut. Tämä osuus jää kuitenkin $22 \%$ :iin kaikista nautakarjatiloista.

Sikatilat keskittyvät asteikon yläpäähän. Parhaassa neljänneksessä oli v. 1976-1978 v. 1978-1980 kaikista sikatiloista $52 \%$ ja v. $1981-1983$ vastaavasti $48 \%$. Alimmassa tuloneljänneksessä sikatiloista oli tutkimuksen alkupuoliskolla vain $12 \%$ ja loppupuoliskolla $16 \%$. Jonkinasteista suhteellista heikentymistä on näin ollen sikatilojen kohdalla tapahtunut.

Suuri osa viljatiloista sijoittuu kaikkina vuosina alimpaan neljännekseen (v. 1976$197853 \%$, v. $1978-198058 \%$ ja v. 1981
-1983 $35 \%$ ). Ilmeisesti nämä viljatilat ovat pinta-alaltaan suhteellisen pieniä. Tutkimusajanjakson lopulla ovat viljatilat kuitenkin selvästi parantaneet sijoitustaan.

Muut tilat -ryhmään kuuluvat tilat ovat keskittyneet jonon ylä- ja alapäihin. Tilojen osuus parhaassa neljänneksessä on tutkimusajanjaksolla hieman laskenut ja toisessa neljänneksessä vastaavasti noussut. Muut tilat -ryhmä on varsin heterogeeninen: mukana on monipuolisen tuotannon tiloja, siipikarjatiloja, yms.

\section{Eri tilakokoluokat}

Tilojen koolla näyttää olevan ratkaiseva vaikutus tilan sijoittumiseen tuloasteikolla. $30-50$ hehtaarin sekä myös yli 50 hehtaarin tilojen sijoitus on selvästi parantunut tarkasteluajanjakson kuluessa. Tämä on nähtävissä erityisen selvästi tarkastelemalla kunkin tilakokoluokan osuutta ylimmässä tuloneljänneksessä (Kuvio 7).

\section{Tilojen siirtyminen tulojonossa}

Sekä maatalousylijäämä että kannattavuuskerroin heikoimmassa neljänneksessä ovat varsin alhaisia kaikkina vuosina. Todettakoon, että alimman kymmenyksen keskimääräinen maatalousylijäämä oli negatiivinen peräti viitenä tutkimusvuotena kahdeksasta. Maatalousylijäämän negatiivisuus on varsin poikkeuksellinen tilanne. Tästä syystä on mielenkiintoista tarkastella erityisesti heikoimpien ja parhaimpien tilojen liikkuvuutta neljänneksestä toiseen tarkasteluajanjaksolla.

Tätä varten aineistosta tulostettiin niiden tilojen lukumäärät, jotka ovat pysyneet samassa tuloluokassa koko ajanjakson ajan. Tarkastelun kohteeksi valittiin vuodet 1976, 1979 ja 1983 edustamaan ajanjakson alku-, keskija loppuvaihetta.

Heikoimmassa neljänneksessä samoja tiloja oli kaikkina kolmena tarkasteluvuotena $53 \%$ ko. neljänneksen tilojen lukumäärästä. Sellaisia tiloja, jotka pysyivät kahtena vuotena kolmesta alimmassa neljänneksessä, oli jo noin 


\section{TILOJEN VAIHTUVUUS ALIMMASSA TULONELJÄNNEKSESSÄ}

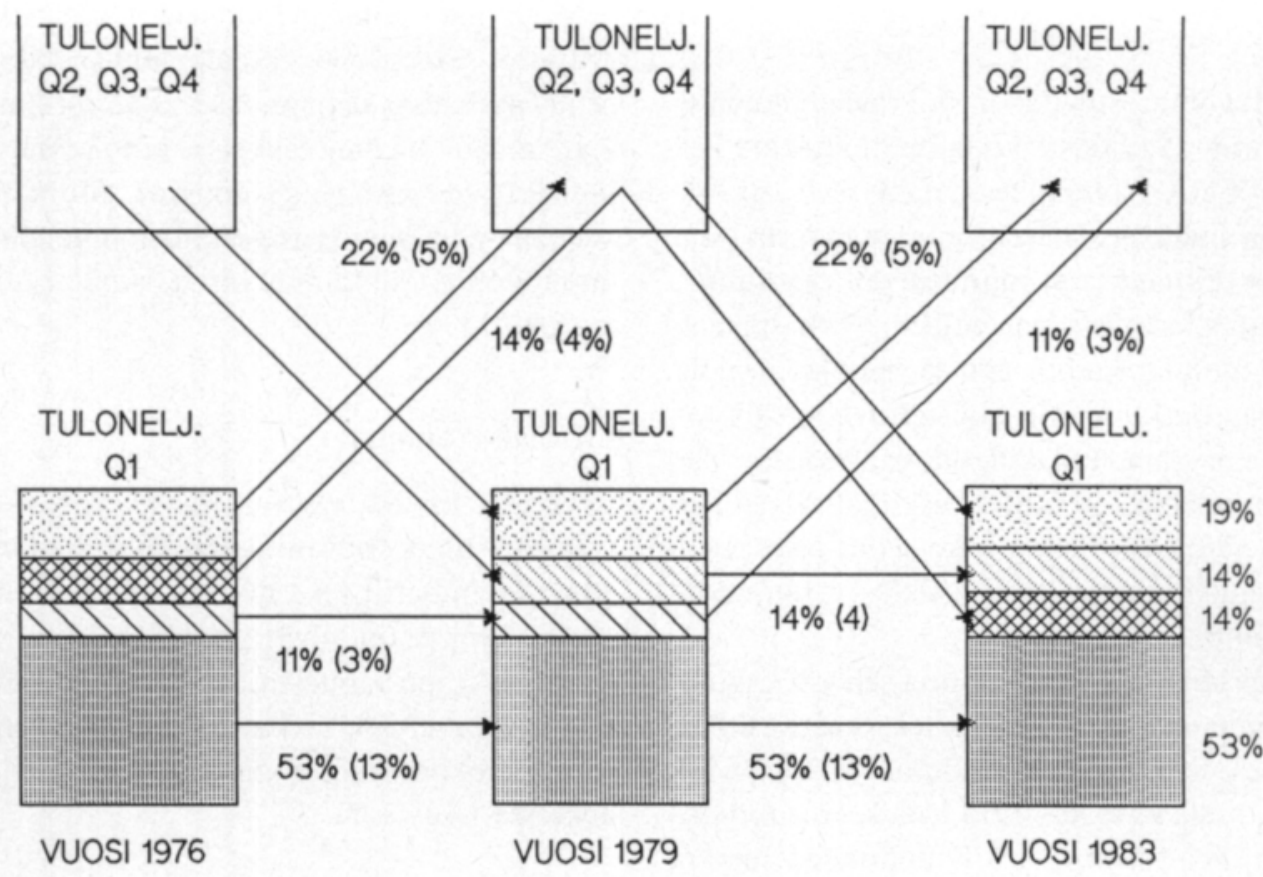

$$
\begin{aligned}
=\text { YHTENÄ VUOTENA ALMMASSA NELJÄNNEKSESSÄ KÄYNEET TILAT } \\
=\text { VUOSINA } 1976 \text { JA } 1983 \text { ALIMPAAN NELJ. KUULUVAT TILAT } \\
=\text { VUOSINA } 1976 \text { JA } 1979 \text { ALMPAAN NELJ. KUULUVAT TILAT } \\
=\text { VUOSINA } 1979 \text { JA } 1983 \text { ALMPAAN NELJ. KUULUVAT TILAT } \\
=\text { KAIKKINA VUOSINA ALMMASSA NELJÄNNEKSESSÄ OLEET TILAT }
\end{aligned}
$$

Kuvio 8. Tilojen vaihtuvuus alimmassa tuloneljänneksessă vuosina 1976, 1979 ja 1983 . Kunakin vuotena alimmasta tuloneljänneksestä (Q1) siirtyvien tilojen lukumäără esitetaaăn prosentteina alimman neljänneksen tilojen lukumäärästả. Sulkeissa olevat prosenttiluvut on laskettu vastaavasti prosentteina kaikista tutkimustiloista.

Fig. 8. The changes of the farms in the lowest income quartile. The percent of farms moving from the lowest quartile to the other quartiles calculated from the number of farms in the lowest quartile.

$80 \%$ neljänneksen tilojen lukumäärästä. Tämä merkitsee sitä, että alimmassa neljänneksessä »tilapäisesti käyviä» tiloja oli noin $20 \%$ neljänneksen tilojen lukumäärästä (Kuvio 8).

Tarkemman kuvan saamiseksi analysoitiin erikseen myös alinta tulokymmenystä. Tilo- jen suhteellinen vaihtuvuus alimmassa kymmenyksessä on luonnollisesti suurempi kuin alimmassa neljänneksessä. Kaikkina kolmena vuotena vain noin $16 \%$ ko. tiloista pysyi alimmassa kymmenyksessä.

Tulojonon alapäässä pitkään pysyvät tilat 
ovat keskittyneet lähes $80 \%$ :sesti alimman neljänneksen ylempään päähän. Maatalousylijäämä toisessa ja kolmannessa kymmenyksessä on tosin hyvin alhainen, mutta ei enää negatiivinen yhtenäkään vuotena. Vaikka alimmassa neljänneksessä lähes puolet tiloista on vaihtunut, voidaan jatkuvasti alimmassa tuloneljänneksessä pysyvien tilojen lukumäärää pitää suurena. Ainoastaan aivan tulojonon alapäässä olevat tilat ovat siellä tilapäisesti ja vaihtuvat suurelta osin vuosittain.
Tulojonon yläpäässä tapahtuvaa yksittäisten tilojen siirtymää tarkasteltiin ylimmän kymmenyksen osalta. Ylimmässä kymmenyksessä on samoja tiloja kaikkina kolmena vuotena peräti $38 \%$ kymmenyksen tilojen lukumäärästä. Kahtena vuotena kolmesta samoja tiloja on $89 \%$ kymmenyksen tiloista. Tästä voidaan tehdä sellainen johtopäätös, että paremmin kannattavien tilojen tulos on stabiilimpi kuin heikommin kannattavien maatilojen.

\section{Kirjallisuus}

Aaltonen, S. 1981. Maatalouden tuloista ja tulonjaosta. Maatal. tal. tutk.lait. tiedonantoja $78: 23-78$.

ANON. 1985. Income disparities in agriculture in the Community. Green Europe 208: 1-16.

Cordts, W., Deerberg, K-H. \& Hanf, C-H. 1983. Infrasectoral profit variation in the German agricultural sector. Dept. of Agric. Econ. Univ. of Kiel. 22 s.

-, Deerberg, K-H. \& Hanf, C-H. 1984. Analysis of the infrasectoral income differences in West German agriculture. Eur. Review of agr. economics 11: 323 -342 .

Hagfors, R. \& Koljonen, K. 1984. Kotitalouksien tulonjako ja toimeentulomahdollisuudet. Taloudellinen suunnittelukeskus. 43 s. Helsinki.

Hanhil.ahtı, H. 1980. Maataloustuotteiden aluetuki ja viljelijän tulot maan eri osissa. Maatal. tal. tutk.lait. tiedonantoja 71: 1-60.

IнамUотіLA, R. 1970. Maataloustulon ja viljelijäperheen työtulon vaihtelusta ja riippuvuudesta tuotannontekijöiden suhteen. Maatal. tal. tutk.lait. julk. 22: 1-31.

Mıккоц. , S. 1983. Maatalouden puhdas tulo, sen vaihtelu ja vaihtelun syyt lypsykarjataloudessa. Pro gradututkielma. Maatalousekonomian laitos. $68 \mathrm{~s}$.

RYynANEN, V. 1970. Tutkimuksia maatalouden tuotantofunktioista Sisă-Suomen kirjanpitoviljelmillä vuosina 1960-66. Acta Agr. Fenn. 120: 1-68.

SNEessens, J. 1979. Dynamics of farm income dispersion in the Belgian Loamy region. Eur. Review of agr. economics 6: 191-208.

Suomela, S. 1952. Tuloslukujen vaihtelusta maatalou- dessa. Summary: On the variability of operating results in agriculture. Erip. Maatal. tiet. aikak. 24: 93-118.

SUOMINEN, R. 1977. Sosiaalisten tulonsiirtojen kohtaanto. Sosiaalisia erikoistutkimuksia. SVT XXXII, 51: $1-109$.

- 1979. Tulojen uudelleenjako Suomessa vuonna 1976. Sosiaalisia erikoistutkimuksia, SVT XXXII, 58: 1168.

TORVELA, M. 1966. Tuotantopanosten kãytőstä ja käytön edullisuudesta maataloudessa Etelä-Suomen alueen kirjanpitoviljelmillä. Maatal. tal. tutk.lait. julk. 8: $1-141$.

TURKKı, A. 1982. Tuotantopanosten käytön vaikutus maidontuotannon kannattavuuteen. Maatalousekonomian lait. julk. 8: 1-65.

Uusıtalo, H. 1982. Tulopolitiikka ja tulonjako. Sosiaalipolitiikka 1982, Sosiaalipoliittisen yhdistyksen vuosikirja 7: 51-102.

von WITZKE, H. 1979. Prices, common agricultural price policy and personal distribution of income in West German agriculture. Eur. Review of agr. economics 6: $61-80$.

- 1983. A model of relative and absolute income differences in agriculture. $78 \mathrm{~s}$. Kiel.

ZaChARIASSE, L.C. 1977. The analysis of variations in farm incomes on arable farms. Eur. Review of agr. economics 4: 149-161.

Ms received January 12, 1987 